Jelica Petrović*,

UDK 159.922.6:364.2

Filozofski fakultet

DOI: $10.19090 / \mathrm{gff} .2018 .1 .289-305$

Univerzitet u Novom Sadu

Ilinka Jović

\title{
BAZIČNE PSIHOLOŠKE POTREBE KOD STARIH: SOCIODEMOGAFSKI KORELATI**
}

Predmet ovog istraživanja bio je da se ispita povezanost osnovnih psiholoških potreba starih osoba sa različitim sociodemografskim varijablama. Osnovni ciljevi istraživanja usmereni su na ispitivanje povezanosti starosti, pola, nivoa obrazovanja, porodične strukture i bračnog statusa sa samodeterminacijom ispitanika u starosti.

Istraživanje je sprovedeno na teritoriji Vojvodine, $\mathrm{u}$ domovima penzionera $\mathrm{u}$ tri veća grada $\mathrm{u}$ toku 2014/15. godine na uzorku od 219 starih osoba (od toga je 74,6\% ženskog pola). Raspon uzrasta bio je od 62 do 92 godine, a prosečna starost ispitanika i starosna medijana su identične i iznose 76 godina.

Tokom ovog istraživanja korišćena je Skala osnovnih psiholoških potreba (Deci \& Ryan, 2004) koja ispituje tri osnovne psihološke potrebe: autonomiju, kompetenciju i povezanost sa drugima. Dobijeni rezultati multivarijatne analize kovarijanse pokazuju da je potreba za povezanošću ona čije zadovoljenje opada sa starošću ispitanika, dok razlike po polu ispitanika nisu registrovane. Rezultati takođe ukazuju na to da postoji značajna razlika $u$ izraženosti potrebe za kompetencijom kod ispitanika različitog stepena obrazovanja, tako da je ova potreba izraženija kod onih koji imaju završenu školu (osnovno ili srednje obrazovanje), nego kod ispitanika koji imaju nepotpunu osnovnu školu ili su bez školske spreme. Porodični i bračni status su statistički značajno povezani sa potrebom za kompetencijom, tj. osobe koje žive same imaju niže rezultate na ovoj dimenziji.

Ključne reči: stari, osnovne psihološke potrebe, teorija samodeterminacije, sociodemografski korelati, povezanost, kompetencija, autonomija

* jelica.petrovic@ff.uns.ac.rs

** Rukopis je nastao u okviru projekta Efekti egzistencijalne nesigurnosti na pojedinca i porodicu u Srbiji (br. 179022), koji finansira Ministartsvo prosvete, nauke i tehnološkog razvoja Srbije 


\section{UVOD}

U pokušajima da se na što bolji način objasni starenje kao jedna od neminovnosti ljudskog postojanja naučnici iz različitih naučnih oblasti su svoja istraživanja usmeravali na različite aspekte procesa starenja. Tako su biološke teorije starenja pomogle u razumevanju bioloških promena koje se tiču zdravstvene i telesne deteriorizacije, sociološke teorije su dale svoj doprinos objašnjenju uticaja društva i kulture na starenje pojedinca i uticaja starenja pojedinaca na društvo, dok su se psihološke teorije mahom bavile ispitivanjem psiholoških promena u procesu starenja. Ono što im je svima bilo zajedničko jeste fokusiranje na negativne fenomene u procesu starenja - opadanje i gubitak telesnih funkcija, redukciju socijalnih uloga, aktivnosti i interakcija kao i na različite vrste psiholoških gubitaka.

Psihološka istraživanja pokazuju da se među gubicima koji u najvećoj meri stresogeno deluju na ostarelu osobu najviše ističe smrt člana porodice ili prijatelja (Alinčić i sar., 2011), zatim povlačenje iz profesionalnog života (penzionisanje), gubitak zdravlja, smanjenje socijalnih kontakata i usamljenost, promene uslova života i životnih navika, institucionalizacija i sl. (Chiriboga, 1982). Sve ove vrste gubitaka se veoma često dovode u vezu sa razvojem depresije u starosti (Bergdahl et al., 2007).

Uprkos činjenici da su u starosti individualne razlike veće nego u bilo kom drugom životnom dobu (Despot Lučanin, 2003), čini se da je u istraživanjima često vršena neopravdana teorijska i metodološka generalizacija koja je doprinosila dvema predrasudama: prvo, da stare možemo posmatrati kao jednu, jedinstvenu i homogenu grupu, a drugo, da je starost životno doba bez ikakvih potencijalnih pozitivnih strana. Tome su naročito doprineli modeli iz biomedicinckog pristupa (Rowe i Kahn, 1997) koji kao odrednice uspešnog starenja vide izostanak psihičkih i telesnih bolesti i poremećaja.

Međutim, zajedno sa činjenicom da se udeo starih osoba u ukupnoj populaciji rapidno povećava, kao i da prosečna dužina života raste, postupno se istraživački fokus pomerio sa tradicionalnog (negativnog) viđenja starosti ka istraživanju mogućnosti za očuvanje ili unapređenje telesne, psihološke i socijalne dobrobiti i kvaliteta života kod starih. Tako koncept »uspešnog starenja« sve više privlači pažnju, pri čemu se naglasak sve više stavlja na psihosocijalne determinante uspešnog starenja: zadovoljstvo životom, socijalno funkcionisanje i psihološke resurse (prema Tucak Junaković i Nekić, 2017). Uprkos činjenici da broj različitih vrsta gubitaka u starosti raste, istraživanja pokazuju da stari ljudi ipak poseduju visoku sposobnost adaptacije (Jopp i Rott, 2006), odnosno da je ključ »uspešnog starenja« upravo proces uspešne adaptacije (Wong, 1989) i pozitivnih 
strategija prevladavanja (Živković i Petrović, 2012). Takođe, nalazi aktuelnih empirijskih istraživanja (uglavnom u ekonomski razvijenjim zemljama) upućuju na važnost optimizma, zadovoljstva životom i smisla života kod starih ljudi (Cosco et al., 2015; Meng i D'Arcy, 2014; Windsor et al., 2015; Golden et al, 2009), te samopoštovanja i integriteta (Tian, 2016; Melendez Moral et al, 2014). Sličnih istraživanja u Srbiji gotovo da nema, te s pravom možemo postaviti pitanje: šta je sa psihološkom dobrobiti starih u našoj zemlji?

Sam pojam dobrobiti odnosi se na optimalno psihološko funkcionisanje i iskustvo, ali se u psihologiji mogu razlikovati minimalno dve koncepcije. Prva potiče iz hedonističke tradicije i veoma često se koristi kao sinonim za sreću (Diener, 2000). Ova subjektivna dobrobit obuhvata globalnu procenu zadovoljstva životom i/ili njegovim aspektima kao i odnos učestalosti doživljavanja prijatnih i neprijatnih emocija (Pavot \& Diener, 1993; Diener et al., 1997). Dakle, prema hedonističkoj koncepciji, srećan je onaj čovek koji je globalno zadovoljan svojim životom i njegovim pojedinim aspektima, te koji doživljava više prijatnih (radost, ponos, zadovoljstvo, sreća) nego neprijatnih emocija (tuga, krivica, stid i sl). Prema drugoj koncepciji koja ima korene u eudamonizmu, psihološka dobrobit pojedinca povezuje se sa ostvarivanjem ljudskih potencijala (Ryan \& Deci, 2001; Ryff \& Singer, 2006). Prema ovom gledištu, zadovoljenje subjektivnih potreba vodi ka trenutnom zadovoljstvu, dok ostvarivanje potreba koje su inherentne ljudskoj prirodi vodi do rasta i razvoja pojedinca.

Rezultati nedavnog istraživanja sprovedenog na starim osobama $u$ Hrvatskoj na temu kako one same definišu uspešno starenje pokazali su da je najveći broj ispitanika važnim za uspešno starenje procenio dobro zdravlje i sposobnost da se brine o sebi, dok su kao najmanje važno ispitanici videli dugovečnost, radni angažman nakon penzionisanja i učenje novih stvari u starosti. Interesantno je da su žene značajno važnijim procenjivale podršku porodice i prijatelja, dok su osobe višeg obrazovanja kontinuirano učenje novih stvari procenjivale važnijim za uspešno starenje (Tucak Junaković i Nekić, 2017). Ovaj tzv. »laički» pristup nas dalje vodi do veoma važnog zaključka da su autonomija (sposobnost brige o sebi), kompetencija (kontinuirano učenje novih znanja) i povezanost sa drugima (podrška porodice i prijatelja) važne psihološke potrebe koje stari ljudi sami prepoznaju kao odlučujuće. Upavo o ovim potrebama govori Teorija samoodređenja (Self Determination Theory - SDT; Deci \& Ryan,1985, 2002) kao urođenim i univerzalnim za svakog pojedinca. Dobrobit se vidi kao direktna posledica zadovoljenja ovih bazičnih psiholoških potreba (Ryan \& Deci, 2000). Autori autonomiju objašnjavaju kao potrebu za iskustvom voljne i samostalne 
regulacije sopstvenih aktivnosti nasuprot preteranoj spoljašnjoj kontroli. Kada pojedincu nedostaje osećaj da sam može da kreira svoje aktivnosti u životu, doživljava manje zadovoljstva i više frustracije (Sheldon \& Kasser, 2001). Kompetencija podrazumeva potrebu za efektivnim interakcijama sa spoljašnjom (fizičkom i socijalnom) sredinom, odnosno potrebu da imamo kontrolu u odnosu na okolinu, te da se osećamo uspešno i sposobno. Ovu psihološku potrebu istraživači vide kao osnov za ostvarenje samopoštovanja i samopouzdanja (Deci \& Ryan, 2000). Povezanost sa drugima predstavlja potrebu za uspostavljanjem bliskih emotivnih veza sa drugim ljudima i grupama (osećanje privrženosti). Obilje literature govori o jakoj povezanosti fizičkog i mentalnog zdravlja sa boljom integracijom u socijalnu mrežu (Berschield \& Reis, prema Deci \& Ryan, 2000). Tako je utvrđeno da je zadovoljenje potrebe za autonomijom i povezanošću dobar prediktor dobrobiti među stanovnicima staračkog doma (Kasser i Ryan, 1996).

Uzimajući u obzir da su istraživanja psihološke dobrobiti kod starih u našoj zemlji veoma retka, da je većina znanja iz ove oblasti „uvezena” iz visoko razvijenih zemalja, te da u pogledu doprinosa različitih sociodemografskih varijabli rezultati istraživanja nisu saglasni, kao predmet istraživanja postavili smo ispitivanje odnosa između bazičnih psiholoških potreba definisanih prema osnovnim pretpostavkama Teorije samoodređenja kod starih osoba u Vojvodini i nekih sociodemografskih pokazatelja (pola, uzrasta, obrazovanja, te bračnog i porodičnog statusa).

\section{METOD}

\section{Uzorak}

Uzorak istraživanja je obuhvatio 219 ispitanika oba pola (74,6\% ženskog) sa teritorije Vojvodine, starosnog raspona od 62 do 92 godine. Prosečna starost ispitanika i starosna medijana su identične i iznose 76 godina. Uzorak je prigodan, a ispitivanje je bilo anonimno i sprovedeno u udruženjima penzionera Novog Sada, Subotice i Zrenjanina. Upitnici su zadavani individualno, bez vremenskog ograničenja za popunjavanje.

Kada je obrazovanje u pitanju, 9,3\% ispitanika nema školsku spremu, $35,6 \%$ ima nepotpunu osnovnu školu, 16,1\% ima završenu osnovnu, 23\% srednju, a $6,8 \%$ višu školu, dok za $10,2 \%$ ispitanika ne postoje takvi podaci. Zbog nedovoljne zastupljenosti ispitanika iz pojedinih grupa, u daljim analizama oni su, prema obrazovanju, podeljeni na grupu ispitanika bez stručne spreme i sa nepotpunom 
osnovnom školom $(44,9 \%)$ i grupu ispitanika sa minimalno završenom osnovnom ili srednjom školom $(44,9 \%)$

Većina ispitanika su udovci ili udovice (65,3\%), dok je njih 24,6\% u braku. Mali broj ispitanika nikad nije bio u braku (6,8\%), a slična situacija je i sa onima koji su razvedeni $(1,7 \%)$.

Najveći broj ispitanika živi samo (72,9\%), a ostatak živi sa supružnikom ili sa porodicom svog deteta. Ispitanici su u daljim analizama svrstani u grupe onih koji su trenutno u braku $(24,6 \%)$ i onih koji nikad nisu bili ili više nisu u bračnoj vezi i žive sami $(73,8 \%)$.

\section{Instrument}

Osim opšteg sociodemografskom upitnika u istraživanju je primenjena Skala bazičnih psiholoških potreba (Basic Need Satisfaction Scale in Life - BNSSL; Deci \& Ryan, 2004) koja ispituje tri osnovne psihološke potrebe. Sastoji se od 21 stavke koje su grupisane u tri supskale (autonomija, kompetencija i povezanost sa drugima). Ispitanici su na sedmostepenoj skali Likertovog tipa (1 - potpuno netačno; 7 - potpuno tačno) procenjivali stepen ispunjenosti sopstvenih psiholoških potreba.

Faktorskom analizom potvrđena je trofaktorska struktura upitnika kao u originalnom istraživanju (Deci \& Ryan, 2004).

U Tabeli 1 prikazani su karakteristični korenovi, procenti objašnjene varijanse za sve tri komponente.

Tabela 1: Komponente upitnika SOPP, njihovi karakteristični korenovi i procenat objašnjene varijanse

\begin{tabular}{llll}
\hline Komponenta & KMO & Karakteristični koren & Objašnjena varijansa \\
\hline Kompetencija & .665 & 1.94 & $32.29 \%$ \\
Autonomija & .655 & 2.12 & $30.30 \%$ \\
Povezanost s drugima & .673 & 2.78 & $34.71 \%$ \\
\hline
\end{tabular}

Od ukupno 21, 7 tvrdnji su namenjene proceni zadovoljenja potrebe za autonomijom, 6 proceni potrebe za kompetencijom, te 8 tvrdnji proceni zadovoljenja potrebe za povezanošću. Primeri stavki sa najvećim komponentnim opterećenjima iz pojedinačnih skala su: „U svakodnevnim situacijama osećam da mogu biti onakav/a kakva sam”; „Uglavnom osećam da mogu slobodno izražavati svoja mišljenja i ideje” (autonomija), „U poslednje vreme naučio/la sam neke zanimljive nove stvari, tj. veštine”; „Ljudi koje poznajem govore mi da sam 
dobar/dobra u onome što radim” (kompetencija); te „Ljude sa kojima se često družim smatram svojim prijateljima”; „Dobro se slažem sa ljudima sa kojima sam u kontaktu" (povezanost).

Pouzdanost interne konzistencije merena Alfa koeficijentom na ovom uzorku je nešto niža. Ona za autonomiju iznosi $\alpha=.53$, za kompetenciju $\alpha=.54$ i za povezanost sa drugima $\alpha=.68$. Relativno niske vrednosti Alfa koeficijenata dobijene su i u drugim istraživanjima na našoj populaciji (Ranđelović i Smederevac, 2011).

\section{Metodi analize podataka}

Statistička obrada podataka vršena je uz pomoć programa SPSS 20.0. Podaci su osim deskriptivnom statistikom, obrađeni i korišćenjem analize glavnih komponenti da bi se utvrdila struktura upitnika Skale osnovnih psiholoških potreba, dok su multivarijatnom analizom varijanse proveravane razlike između formiranih grupa ispitanika po odabranim sociodemografskim varijablama.

\section{REZULTATI}

\section{Deskripitivna statistika}

U tabeli 2 prikazani su deskriptivni pokazatelji za izraženost psiholoških potreba kod starih. Rezultati ukazuju na postojanje nešto veće varijabilnosti u stepenu izraženosti psihološke potrebe za kompetencijom, koja je ujedno i najmanje zadovoljena potreba na ispitivanom uzorku starih.

Tabela 2: Deskriptivni pokazatelji, pokazatelji karakteristika distribucije rezultata $i$ pokazatelj pouzdanosti varijabli upitnika BNSSL

\begin{tabular}{llllll}
\hline Psihološke potrebe & AS & SD & Sk & Ku & $\alpha$ \\
\hline Kompetencija & 4.89 & 1.60 & -.22 & -.38 & .54 \\
Autonomija & 5.11 & .98 & -.36 & -.11 & .53 \\
Povezanost s drugima & 6.25 & .78 & -.21 & -.43 & .68
\end{tabular}

Napomena: aritmetičke sredine (AS), standardne devijacije (SD), koeficijent asimetrije Skjunis (Sk), koeficijent izduženosti - Kurtozis (Ku), i Kronbah alfa koeficijent ( $\alpha$ ). 
Relacije osnovnih psiholoških potreba i sociodemografskih varijabli

Multivarijatnom analizom kovarijanse ispitane su povezanosti između rezultata na dimenzijama Skale osnovnih psiholoških potreba i pola i starosti ispitanika. Tri zavisne varijable predstavljale su rezultate na tri dimenzije Skale osnovnih psiholoških potreba, nezavisna varijabla sa dva nivoa reprezentovala je pol ispitanika, a starost ispitanika uvrštena je kao kovarijat. Rezultati su pokazali da ne postoji razlika u izraženosti psiholoških potreba između muških i ženskih ispitanika, ali da postoji povezanost između starosti i ovih dimenzija (Tabela 3).

Tabela 3: Efekti pola i starosti na tri dimenzije Skale osnovnih psiholoških potreba.

\begin{tabular}{llllll}
\hline Varijabla & $\begin{array}{l}\text { Vilksova } \\
\text { lambda }\end{array}$ & $\begin{array}{l}\text { Vrednost } \\
(F)\end{array}$ & $\begin{array}{l}\text { testa } \\
(p)\end{array}$ & $\begin{array}{l}\text { Značajnost } \\
\left(\eta^{2}\right)\end{array}$ & $\begin{array}{l}\text { Veličina } \\
\text { efekta }\end{array}$ \\
\hline Konstanta & .890 & 4.674 & .004 & .110 & \\
Starost & .894 & 4.468 & $.005^{*}$ & .106 \\
Pol & .980 & .753 & .523 & .020 \\
\hline
\end{tabular}

Analize efekta starosti pokazale su da je uzrast ispitanika statistički značajno povezan s povezanošću sa drugima, i to tako da se smanjuje povezanost sa drugima sa starenjem (Tabela 4).

Tabela 4: Parcijalni doprinos starosti u predviđanju dimenzija Skale osnovnih psiholoških potreba.

\begin{tabular}{|c|c|c|c|}
\hline \multirow[b]{2}{*}{ Varijabla } & Nestandardizovani & \multirow{2}{*}{$\begin{array}{l}\text { Vrednost testa } \\
(t)\end{array}$} & \multirow{2}{*}{$\begin{array}{l}\text { Značajnos } \\
(p)\end{array}$} \\
\hline & $\begin{array}{l}\text { regresioni koeficijent } \\
\text { (B) }\end{array}$ & & \\
\hline Kompetencija & .013 & .975 & .332 \\
\hline Autonomija & .001 & .111 & .912 \\
\hline $\begin{array}{l}\text { Povezanost s } \\
\text { drugima }\end{array}$ & -.040 & -3.229 & .002 \\
\hline
\end{tabular}

Pošto su rezultati pokazali da pol ne pravi razliku po tri dimenzije Skale osnovnih psiholoških potreba, ovaj parametar više nije uziman u obzir u daljim analizama.

Serijom multivarijantnih analiza varijanse ispitana je razlika između rezultata ispitanika na tri dimenzije Skale osnovnih psiholoških potreba i to prema njihovom stepenu obrazovanja (završeno i nezavršeno osnovno obrazovanje), 
bračnom statusu (trenutno u braku i nije trenutno $u$ braku) i porodičnom statusu (živi sam ili živi s nekim).

Kada je u pitanju stepen obrazovanja, rezultati multivarijantne analize varijanse pokazali su da postoji razlika po tri dimenzije Skale osnovnih psiholoških potreba između ispitanika razlčitog stepena obrazovanja (Tabela 5).

Tabela 5: Efekti obrazovanja na tri dimenzije Skale osnovnih psiholoških potreba.

\begin{tabular}{llllll}
\hline Varijabla & $\begin{array}{l}\text { Vilksova } \\
\text { lambda }\end{array}$ & $\begin{array}{l}\text { Vrednost } \\
(F)\end{array}$ & $\begin{array}{l}\text { Značajnost } \\
(p)\end{array}$ & $\begin{array}{l}\text { Veličina } \\
\left(\eta^{2}\right)\end{array}$ & efekta \\
\hline Konstanta & .944 & 2.014 & .117 & .056 & \\
Obrazovanje & .740 & 11.951 & .000 & .260 & \\
\hline
\end{tabular}

Ispitanici koji su završili minimalno osnovnu školu postižu više rezultate na dimenziji kompetencije, dok razlika među ispitanicima ne postoji kada su u pitanju druge dve dimenzije (Tabela 6).

Tabela 6: Razlike u rezultatu na tri dimenzije Skale osnovnih psiholoških potreba prema obrazovanju.

\begin{tabular}{llllll}
\hline Varijabla & $\begin{array}{l}\text { Prosek } \\
\text { (bez } \\
\text { osnovne } \\
\text { škole) }\end{array}$ & $\begin{array}{l}\text { Prosek } \\
\text { (sa } \\
\text { završenom } \\
\text { osnovnom } \\
\text { školom) }\end{array}$ & $\begin{array}{l}\text { Vrednost } \\
\text { testa }(F)\end{array}$ & $\begin{array}{l}\text { Značajnost } \\
(p)\end{array}$ & $\begin{array}{l}\text { Veličina } \\
\text { efekta }\left(\eta^{2}\right)\end{array}$ \\
\hline $\begin{array}{l}\text { Kompetencija } \\
\text { Autonomija }\end{array}$ & -.366 & .542 & 27.946 & .000 & .212 \\
$\begin{array}{l}\text { Povezanost s } \\
\text { drugima }\end{array}$ & -.116 & -.178 & .120 & .729 & .001 \\
\hline
\end{tabular}

Drugom multivarijantnom analizom varijanse ispitane su razlike između ispitanika koji su trenutno u braku i onih koji nisu (Tabela 7). Rezultati su pokazali da bračni status ima efekta na rezultate upitnika. 
Tabela 7: Efekti bračnog statusa na tri dimenzije Skale osnovnih psiholoških potreba.

\begin{tabular}{llllll}
\hline Varijabla & $\begin{array}{l}\text { Vilksova } \\
\text { lambda }\end{array}$ & $\begin{array}{l}\text { Vrednost } \\
\text { testa }(F)\end{array}$ & $\begin{array}{l}\text { Stepeni } \\
\text { slobode }(d f)\end{array}$ & $\begin{array}{l}\text { Značajnost } \\
(p)\end{array}$ & $\begin{array}{l}\text { Veličina } \\
\text { efekta }\left(\eta^{2}\right)\end{array}$ \\
\hline $\begin{array}{l}\text { Konstanta } \\
\text { Bračni } \\
\text { status }\end{array}$ & .952 & 1.866 & $3(112)$ & .139 & .048 \\
\hline
\end{tabular}

Ispitanici koji su u braku postižu više skorove na supskali kompetencije, ali razlika među ispitanicima ne postoji kada su u pitanju druge dve dimenzije (Tabela 8).

Tabela 8: Razlike u rezultatu na tri dimenzije Skale osnovnih psiholoških potreba prema bračnom statusu.

\begin{tabular}{lllllll}
\hline Varijabla & $\begin{array}{l}\text { Prosek } \\
(\mathrm{u} \\
\text { braku) }\end{array}$ & $\begin{array}{l}\text { Prosek } \\
(\text { nije u } \\
\text { braku })\end{array}$ & $\begin{array}{l}\text { Stepeni } \\
\text { slobode } \\
(d f)\end{array}$ & $\begin{array}{l}\text { Vrednost } \\
\text { testa }(F)\end{array}$ & $\begin{array}{l}\text { Značajnost } \\
(p)\end{array}$ & $\begin{array}{l}\text { Veličina } \\
\text { efekta } \\
\left(\eta^{2}\right)\end{array}$ \\
\hline Kompetencija & .684 & -.223 & $1(114)$ & 20.615 & .000 & .153 \\
$\begin{array}{l}\text { Autonomija } \\
\begin{array}{l}\text { Povezanost } \\
\text { drugima }\end{array}\end{array}$ & .015 & -.024 & $1(114)$ & .033 & .857 & .000 \\
\hline
\end{tabular}

Multivarijantnom analizom varijanse ispitane su i razlike između ispitanika koji žive sami i onih koji žive s nekim drugim, bilo sa supružnikom, supružnikom i decom ili porodicom svog deteta. Rezultati su pokazali da i to ima uticaj na njene rezultate na Skali osnovnih psiholoških potreba (Tabela 9).

Tabela 9: Efekti porodičnog statusa na tri dimenzije Skale osnovnih psiholoških potreba.

\begin{tabular}{llllll}
\hline Varijabla & $\begin{array}{l}\text { Vilksova } \\
\text { lambda }\end{array}$ & $\begin{array}{l}\text { Vrednost } \\
\text { testa }(F)\end{array}$ & $\begin{array}{l}\text { Stepeni } \\
\text { slobode }(d f)\end{array}$ & $\begin{array}{l}\text { Značajnost } \\
(p)\end{array}$ & $\begin{array}{l}\text { Veličina } \\
\text { efekta }\left(\eta^{2}\right)\end{array}$ \\
\hline $\begin{array}{l}\text { Konstanta } \\
\text { Bračni } \\
\text { status }\end{array}$ & .963 & 1.441 & $3(112)$ & .235 & .037 \\
\hline
\end{tabular}


Ponovo je razlika zabeležena jedino u slučaju kompetencije. Ispitanici koji žive sami imaju niže rezultate na dimenziji kompetencije u odnosu na one koji žive s drugima (Tabela 10).

Tabela 10: Razlike u rezultatu na tri dimenzije Skale osnovnih psiholoških potreba prema porodičnom statusu.

\begin{tabular}{lllllll}
\hline Varijabla & $\begin{array}{l}\text { Prosek } \\
(\text { živi } \\
\text { sam) }\end{array}$ & $\begin{array}{l}\text { Prosek } \\
(\text { živi s } \\
\text { nekim) }\end{array}$ & $\begin{array}{l}\text { Stepeni } \\
\text { slobode } \\
(d f)\end{array}$ & $\begin{array}{l}\text { Vrednost } \\
\text { testa }(F)\end{array}$ & $\begin{array}{l}\text { Značajnost } \\
(p)\end{array}$ & $\begin{array}{l}\text { Veličina } \\
\text { efekta } \\
\left(\eta^{2}\right)\end{array}$ \\
\hline Kompetencija & -.224 & .626 & $1(114)$ & 18.513 & .000 & .140 \\
$\begin{array}{l}\text { Autonomija } \\
\text { Povezanost s } \\
\text { drugima }\end{array}$ & -.017 & .027 & $1(114)$ & .041 & .840 & .000 \\
\hline
\end{tabular}

\section{DISKUSIJA}

Predmet ovog istraživanja bio je da se ispita povezanost osnovnih psiholoških potreba starih osoba sa različitim sociodemografskim varijablama. Osnovni ciljevi istraživanja usmereni su na ispitivanje povezanosti starosti, pola, nivoa obrazovanja, porodične strukture i bračnog statusa sa samodeterminacijom ispitanika u starosti.

Analizom efekata starosti pokazano je da je ona u značajnoj vezi jedino sa dimenzijom povezanosti sa drugima $i$ da se povezanost sa drugima smanjuje sa starenjem.

Potreba za povezanošću uključuje osećaj međusobnog poštovanja, brige i povezanosti sa drugima (Baumeister \& Leary, 1995.). Širina i dubina socijalnih odnosa često se smatraju najboljim prediktorima subjektivne dobrobiti (Helliwell, Putnam, 2004). Povezanost sa drugima postaje značajnija u starom dobu, nego u bilo kom drugom, jer socijalna mreža ublažava neke od stresova koji prate starenje (Cosco et al., 2015; Živković i Petrović, 2012). Rezultati istraživanja nedvosmisleno potvrđuju da osobe koje su bolje integrisane u socijalnu mrežu i koje imaju zadovoljavajuće odnose sa drugima imaju tendenciju da duže žive, te imaju bolje mentalno i fizičko zdravlje (Reis et al., 2000). To je u skladu i sa Teorijom samoodređenja koja tvrdi da su ljudi najsrećniji i najzdraviji kada im okolina i unutrašnji procesi dopuštaju osećaj uspešnosti, mogućnosti izbora i povezanosti u svakodnevnom životu (prema Deci \& Ryan, 2000). 
Polazeći od činjenice da su gubici u sferi međuljudskih odnosa češći u starosti, očekivane su promene unutar socijalnih kontakata. Teorija socioemocionalne selektivnosti tvrdi da sa starenjem socijalna mreža postaje sve selektivnija, tj. ona se smanjuje u korist vrlo malog broja visokokvalitetnih bliskih odnosa (Fung et al.; 2001; Lang et al., 1998). Rezultat ovog istraživanja koje nam govori da se sa starenjem javlja veća ugroženost potrebe za povezanošću u skladu je sa rezultatima studija koje naglašavaju usamljenost kao čest fenomen kod starih osoba (Golden et al., 2009; Lauder et al.; Victor et al., 2006). Svakako treba imati u vidu i specifičnost uzorka u kome se našlo $65,3 \%$ udovaca i udovica koji žive sami, a udovištvo se pokazuje kao najjači prediktor usamljenosti kod starih (Beal, 2006; Golden et al, 2009).

$\mathrm{U}$ cilju ispitivanja međupolnih razlika u dimenzijama samodeterminacije dobijeno je da pol ne pravi razliku po tri dimenzije Skale osnovnih psiholoških potreba. Iako je pol ispitanika često posmatran kao varijabla koja bi mogla uticati na zadovoljstvo životom, dosadašnja istraživanja daju oprečne rezultate. Naime, Dajner (Diener, 2000) smatra da je razlika između muškaraca i žena toliko mala da je zanemarljiva i iznosi jednu petinu standardne devijacije. Neki drugi autori smatraju da, iako nivo blagostanja kod žena i muškaraca može biti isti, postoji razlika u njegovoj strukturi.

Dalji rezultati pokazali su da postoji značajna razlika u izraženosti psihološke potrebe za kompetencijom kod ispitanika različitog stepena obrazovanja. Naime, kod starih ispitanika koji imaju završenu neku školu (osnovno ili srednje obrazovanje) $\mathrm{u}$ odnosu na ispitanike sa nepotpunom osnovnom školom i one bez školske spreme nema razlike u psihološkim potrebama za autonomijom i povezanošću sa drugima, dok je potreba za kompetentnošću izraženija kod obrazovanijih. Ovaj podatak nam se čini smislenim s obzirom na to da obrazovanje pruža prilike za ovladavanje različitim znanjima i veštinama i dovodi do osećanja efikasnosti i povećanog osećaja kontrole i izbora u životu. Rezultati drugih istraživanja potvrđuju da je nivo stručne spreme pozitivno povezan sa zadovoljstvom i srećom (Pastuović, 2012), objašnjavajući da viši nivoi stručne spreme, naročito u ekonomski naprednim zemljama, obezbeđuju veći raspon mogućnosti. Verovatno je da obrazovanije osobe više uviđaju važnost kontinuiranog učenja, te se same više uključuju u različite oblike formalnog i neformalnog obrazovanja. Kompetencija ima posebnu ulogu u starosti, naročito kada autonomija i nezavisnost opadaju. Različiti istraživači ističu potrebu za kompetencijom kao glavni preduslov samopoštovanja i samopouzdanja (Deci \& Ryan, 2000). S druge strane, kako primećuju neki autori (Tucak Junaković i Nekić, 
2017), u američkoj individualističkoj i visoko kompetitivnoj kulturi kontinuirano učenje se smatra preduslovom uspešnog starenja, dok na našem podneblju društvo ne smatra ovu potrebu uobičajenom kod starih.

Multivarijatnom analizom varijanse ispitane su razlike između ispitanika koji žive sami i onih koji žive sa nekim - bilo sa supružnikom ili porodicom svog deteta. Rezultati ovoga istraživanja su pokazali da je porodični i bračni status statistički značajno povezan sa potrebom za kompetencijom, u smislu da osobe koje žive same imaju niže rezultate na dimenziji kompetencije u odnosu na one koji žive sa drugima.

Visok procenat starih koji žive sami u ovom istraživanju $(72,9 \%) \mathrm{u}$ skladu je sa trendom koji traje poslednjih 40 godina u gotovo celom svetu, od kada je došlo je do opadanja udela starijih osoba koji žive zajedno sa decom (Sundstrom, 1994, prema: Schaie i Willis, 2001). Taj pad je zabeležen u svim zemljama u kojima se zbiva kretanje od pretežno seoskih ka gradskim sredinama, što čini zajedničko stanovanje težim (Gille, 1992, prema: Schaie i Willis, 2001). Dobijeni rezultat da samački život umanjuje osećaj kompetencije kod starih može se razumeti u svetlu istraživačkih nalaza koji naglašavaju sledeće - socijalna podrška veoma je važan resurs koji osobu pokreće na to da jača osećaj sopstvenih sposobnosti i delotvornosti u onome što radi. Neka od ranijih istraživanja pokazala su da, na primer, uspešno obavljanje supružničke uloge povećava efikasnost u suočavanju sa stresom tako što povećava samopouzdanje pojedinca (Diener et al., 2002; Burton i sar., 2003). Otuda je moguće da ljudima koji žive sami, a naročito udovcima, samački način života smanjuje samopouzdanje, što čini da se osećaju niskokompetentnim. Pri tome, osećanju kompetencije koja je u korišćenom instrumentu definisana kroz uspeh, tj. kroz čovekovu sposobnost i potrebu da bude dobar u onome što radi, neophodna je i eksterna evaluacija („ogledalo”) koja u samačkom životu često izostaje. Stoga postoji mogućnost da relaciju između bračnog i porodičnog uređenja i osećanja kompetencije moderira potreba za povezanošću sa drugima. Naime, kroz socijalnu razmenu, primanje i pružanje podrške (stari) ljudi doživljavaju nezavisnost, dostojanstvo, samopoštovanje koje im podstiče osećanje uspešnosti (Čudina-Obradović i Obradović, 2004; Tanner, 2007).

U zaključku možemo istaći da su osnovne psihološke potrebe kod starih različito povezane sa sociodemografskim karakteristikama. Potreba za povezanošću sa drugima se pokazala kao potreba čije zadovoljenje opada sa starošću ispitanika. Potreba za kompetencijom pokazala se kao ugroženija kod starih koji su neobrazovani i kod onih koji žive sami. S obzirom na to da su većina ispitanih 
starih osoba udovci/udovice i da žive sami, možemo pretpostaviti da je boravak u domovima penzionera jedan od načina na koji oni kompenzuju osećanje usamljenosti i tako zadovoljavaju potrebu za povezanošću, a time i za kompetencijom. Potreba za autonomijom na ispitivanom uzorku nije povezana sa sociodemografskim odlikama. Međutim, treba još jednom naglasiti da su ovaj uzorak činile osobe koje se aktivno druže u domovima penzionera (dakle, dobrog opšteg zdravstvenog stanja) ili žive izvan institucija, u sopstvenim domovima. Možemo pretpostaviti da bismo dobili drugačije rezultate kod starijih osoba narušenog zdravlja kao i kod onih starih koji su smešteni u institucije (npr. u bolnicama ili domovima za starije i nemoćne).

$\mathrm{Na}$ kraju, neophodno je naglasiti izvesnu rezervu prema dobijenim rezultatima iz nekoliko razloga. Skala zadovoljenja bazičnih psiholoških potreba pokazala je nisku pouzdanost na nivou supskala. Uprkos tome oni ipak mogu biti korisni kao polazna tačka za naredni korak koji bi vodio u pravcu promišljanja i validiranja konceptualnog modela osnovnih psiholoških potreba kod starih. Uzroke nižih vrednosti pouzdanosti možemo potražiti u nedoslednom uključivanju različitih nivoa opštosti kada je u pitanju formulacija stavki naročito unutar supskala autonomija i kompetentnost. Naime, operacionalizacija konstrukata ovako visokog nivoa opštosti može biti ozbiljna prepreka ispitanicima nižeg nivoa obrazovanja, ali i pretnja teorijskim postavkama na kojima počivaju ovi konstrukti. Finijim specifikovanjem i konkretnijom formulacijom stavki, kao i povećanjem njihovog broja, mogli bi se postići bolji pokazatelji pouzdanosti za ovaj instrument. Osim toga, potrebno je u daljim istraživanjima proveriti i druge merne karakteristike ovog instrumenta. Na taj način bi se doprinelo kreiranju instrumenta koji bi se koristio u budućim istraživanjima procene psiholoških potreba koje nesumnjivo predstavljaju veoma važan fenomen.

Drugo, kako je već istaknuto, individualne razlike u starosti su veće nego u svim ostalim životnim razdobljima, te se dobijeni rezultati mogu uopštiti samo na zdrave stare pojedince iz gradskih sredina koji žive $u$ svojim domovima. Istraživanja psihologije starih u Srbiji su još uvek veoma oskudna. Budući da se Srbija svrstava među zemlje koje rapidno stare, svaka istraživačka pažnja usmerena na ispitivanje saznanja koja mogu doprineti boljem razumevanju naših starih i njihovih potreba je dobrodošla. 
Jelica Petrović, Ilinka Jović

\section{BASIC PSYCHOLOGICAL NEEDS OF THE ELDERLY: SOCIODEMOGRAPHIC CORRELATES}

\section{Summary}

The main subject of this research was the examination of the relationship between the basic psychological needs of the elderly and different socio-demographic variables. The goals of the research were focused on examining relations of age, gender, level of education, family structure and marital status with the self-determination of the elderly.

The survey was conducted in three cities in the Autonomous Province of Vojvodina, in retirement homes during 2014/15. The sample consisted of 219 elderlies ( $74.6 \%$ female). The age range was between 62 and 92 years old, and the average age of respondents was 76 years. Basic psychological needs (autonomy, competence and relatedness) were measured with the Scale of basic psychological Needs (Deci \& Ryan, 2004).

The obtained results of the multivariate analysis of covariates showed that the relatedness decreases with the age of the respondents, while gender differences were not registered. The results also indicate that there was a significant difference in competence among respondents of varying degrees of education. Competence is higher in those who have completed school (primary or secondary education), compared to incomplete elementary school and respondents without schooling. Differences between respondents living alone and those living with their spouse or family of their child were also examined. The results have shown that family and marital status are significantly related to the competence, so that the elderly living alone have lower results in this area compared to those who live with others.

Since most of the elderly examinees in this research are widowed and live alone, we assumed that staying in retirement homes is one of the ways to compensate for the feeling of loneliness, and thus meet the need for relatedness and, therefore, competence. The need for autonomy in the examined sample was not related to socio-demographic characteristics. However, it should be emphasized that the sample in this research consisted of the elderly who actively socialize in retirement homes (i.e. those in good general health) and live outside institutions, in their own homes. It is assumed that the results could be different in the sample of the elderly who suffer from ill health, as well as in those who are accommodated in care institutions.

Key words: elderly, basic psychological needs; Self-determination theory, sociodemographic correlates, relatedness, autonomy, competence 


\section{LITERATURA}

Alinčić, M, Zotović, M., Petrović, J. (2011). Izvori i stepen stresa kod starih osoba u Srbiji. Knjiga apstrakata: Savremeni trendovi u psihologiji, 168-169.

Baumeister, R., \& Leary, M. R. (1995). The need to belong: Desire for interpersonal attachments as a fundamental human motivation. Psychological Bulletin,117, 497-529.

Beal C. 2006. Loneliness in older women: a review of the literature. Issues Ment Health Nursery 27, 795-813.

Bergdahl, E \& Allard, P \& Lundman, Berit \& Gustafson, Yngve. (2007). Depression in the oldest old in urban and rural municipalities. Aging \& mental health 11, 570-578.

Burton, E., Stice, E., \& Seeley, J. R. (2004). A prospective test of the stressbuffering model of depression in adolescent girls: No support once again. Journal of Consulting and Clinical Psychology,72(4), 689-697.

Chiriboga, D. A. (1982). An examination of life events as possible antecedents to change. Journal of Gerontology, 37, 595-601.

Cosco, T. D., Stephan, B. C. M. i Bryne, C. (2015) Validation of an a priori, index model of successful aging in a population-based cohort study: the successful aging index, International Psychogeriatrics, 27 (12), 19711977.

Čudina-Obradović, M. \& Obradović, J. (2004). Psihosocijalne pretpostavke skrbi za stare ljude. Revija za socijalnu politiku, 11 (2), 177-192.

Deci, E. L., \& Ryan, R. M. (1985). Intrinsic motivation and self-determination in human behavior. New York: Plenum.

Deci, E. L., \& Ryan, R. M. (2000) The „what” and „why” of goal pursuits: Human needs and the self-determination of behavior. Psychological Inquiry, 11(4),227-268

Deci, E. L., \& Ryan, R. M. (2002). Handbook of Self-Determination Research. Rochester: The University of Rochester Press. Retrieved November 20, 2009 from: http://books.google.com

Deci, E. L., \& Ryan, R. M. (2004). Basic Psychologycal Need Scales. Retrieved from: http://www.psych.rochester.edu/SDT/

Despot Lučanin, J. (2003). Iskustvo starenja. Doprinos teoriji starenja. Jastrebarsko: Naklada Slap

Diener, E. (2000). Subjective well-being. The science of happiness and a proposal for a national index. American Psychologist 55 (1), 34-43 
Diener, E., Suh, E., \& Oishi, S. (1997). Recent findings on subjective well-being. Indian Journal of Clinical Psychology, 24, 25-41.

Fung, H. H., Carstensen, L. L., \& Lang, F. R. (2001). Age-related patterns of social relationships among African-Americans and Caucasian-Americans: Implications for socioemotional selectivity across the life span. International Journal of Aging and Human Development, 52, 185-206.

Golden J, Conroy RM, Bruce I, Denihan A, Greene E, Kirby M, Lawlor BA. (2009). Loneliness, social support networks, mood and wellbeing in community-dwelling elderly. International Journal of Geriatric Psychiatry 24 (7), 694-700

Helliwell, J.F. and Putnam, R.D. (2004) The Social Context of Well-Being. Philosophical Transactions of the Royal Society B, 359, 1435-1446. Retrieved from: http://econ.arts.ubc.ca/jhelliwell/papers/Helliwell-PutnamPTRSL2004.pdf

Jopp, D., Rott C. (2006). Adaptation in very old age: exploring the role of resources, beliefs, and attitudes for centenarians' happiness. Psychology of Aging 21(2), 266-280

Kasser, T., \& Ryan, R. M. (1996). Further examining the American dream: Differential correlates of intrinsic and extrinsic goals.Personality and Social Psychology Bulletin 22, 80-87.

Lang, F. R., Staudinger, U. M., \& Carstensen, L. L. (1998). Perspectives on socioemotional selectivity in late life: How personality and social context do (and do not) make a difference. The Journals of Gerontology: Psychological Sciences, 53, 21-30.

Lauder W, Mummery K, Jones M, Caperchione C. 2006.A comparison of health behaviours in lonely and non-lonelypopulations.Psychology Health Medicine 11, 233-245

Meléndez Moral J. C.; Fortuna Terrero, F.B.; Sales Galán, A.; Mayordomo Rodríguez, T. (2014) Effect of integrative reminiscence therapy on depression, well-being, integrity, self-esteem, and life satisfaction in older adults, The Journal of Positive Psychology, 10 (3), 240-247.

Meng, X. i D'Arcy, C. (2014) Successful aging in Canada: Prevalence and predictors from a population-based sample of older adults, Gerontology, 60 (1), 65-72.

Pastuović, N. (2012). Obrazovanje i razvoj: kako obrazovanje razvija ljude $i$ mijenja društvo, a kako društvo djeluje na obrazovanje. Zagreb: Institut za društvena istraživanja u Zagrebu i Učiteljski fakultet Sveučilišta u Zagrebu. 
Pavot, W., \& Diener, E. (1993). Review of the satisfaction with life scale. Psychological Assessment, 5(2), 164-172.

Ranđelović, K.; Smederevac, S. (2011). Relacije životnih ciljeva, bazičnih psiholoških potreba i dobrobiti. Primenjena psihologija, 3, 263-278

Reis, H. T, Sheldon, K. M., Gable, S. L., Roscoe, J., \& Ryan, R. M. (2000). Daily well-being: The role of autonomy, competence, and relatedness. Personality and Social Psychology Bulletin, 26, 419-435.

Rowe, J. W. i Kahn, R. L. (1997) Successful aging, The Gerontologist, 37 (4), 433440.

Ryan, R. M. \& Deci, E. L. (2000). Self-Determination theory and the facilitation of intrinsic motivation, social development and well-being. American Psychologist, 55(1), 68-78.

Ryan, R. M., \& Deci, E. L. (2001). On happiness and human potentials: A review of research on hedonic and eudaimonic well-being. Annual Review of Psychology, 52, 141-166.

Ryff, C. D., \& Singer, B., H. (2006). Best news yet on six-factor model of wellbeing. Social Science Research, 35, 1103-1119.

Schaie, KW, Willis, SL (2001): Psihologija odrasle dobi i starenja. Zagreb: Naklada Slap.

Sheldon, K. M., \& Kasser, T. (2001). Getting older, getting better? Personal strivings and psychological maturity across the life span. Developmental Psychology, 37, 491-501.

Tanner, D. (2007). Starting with lives: Supporting older people's strategies and ways of coping. Journal of Social Work, 7 (1), 7-30.

Tian, Q. (2016). Intergeneration social support affects the subjective well-being of the elderly: Mediator roles of self-esteem and loneliness. Jounal of Health Psychology 21(6), 1137-1144.

Tucak Junaković, I., Nekić, M. (2016). Percepcija uspješnog starenja u starijih osoba. Acta Iadertina, 13(2), 0-0. Preuzeto s https://hrcak.srce.hr/190147

Victor CR, Scambler SJ, Marston L,et al. 2006. Older people'sexperiences of loneliness in the UK: does gender matter? SocialPolicy Society 5: 27-38.

Windsor, T. D., Curtis, R. G. i Luszcz, M. A. (2015) Sense of purpose as a psychological resource for aging well, Developmental Psychology, 51 (7), 975-986.

Živković, T., Petrović, J. (2012). Prevladavanje stresa u starosti. Primenjena psihologija, 5 (4), 393-412 